\title{
Cosmopolitan political community: why does it feel so right?
}

\section{Kate Nash}

Nature should thus be thanked for fostering social incompatibility, enviously competitive vanity, and insatiable desires for possession or even power.

Immanuel Kant ${ }^{1}$

We are all Americans.

Le Monde (12 September 2001)

\begin{abstract}
Identification with a national community is typically associated with "hot" emotions, and opposed to "cool" cosmopolitanism as an ideal. This paper will consider neo-Kantian understandings of cosmopolitan citizenship to be realised through human rights in which "hot" national feeling and "cool" cosmopolitanism are implicitly opposed in this way. I will argue that the dichotomy makes it difficult to see how "warm" cosmopolitanism is actually developing in political communities organised by Western states, in less rationalist ways than is suggested by neo-Kantians and in association with, rather than in opposition to, national feeling. Human rights are developing in part through humanitarian intervention that is of questionable legitimacy in democratic terms. It is less likely to be judged "right" (or wrong) according to reasoned normative principles with which cosmopolitanism is associated in neo-Kantianism, and more likely to be consented to on the basis of sentimental "popular cosmopolitanism" that feels right.

Identification with a national community is typically associated with "hot" emotions, and opposed to "cool" cosmopolitanism as an ideal. 2 "Hot" communicates intensity of feeling experienced as such: while the causes and the precise coordinates of feeling may be questioned or confused (the premise of psychoanalysis), that there is emotion is not in doubt. "Hot" emotions also suggest a direct link between emotion and motivation to act that is relatively unreflexive: these are the emotions that overwhelm reason and self-
\end{abstract}


interest. "Cool" emotions are experienced as more diffuse, where there is questioning of what is felt and where motivation to act is taken to be based on reflection. ${ }^{3}$ In this paper we will consider how the oversimplified characterization of national feeling as "hot" and cosmopolitanism as "cool" tends to reify the former and idealize the latter. We will consider cosmopolitanism in the neo-Kantian terms of human rights, in which, although emotion has not been addressed directly, "hot" national feeling and "cool" cosmopolitanism are implicitly opposed in this way. I will argue that the dichotomy makes it difficult to see how "warm" cosmopolitanism is actually developing in political communities organized by western national states, in less rationalist ways than is suggested by neo-Kantians and in association with, rather than in opposition to, national feeling.

Despite the wide variety of groups that have considered themselves and been considered as nations, and despite differences of emphasis in accounts of nationbuilding and nationalism, most sociologists working in this area agree on three points. Firstly, a nation is distinguished from other, superficially similar groups, like ethnic or racial "peoples," in that nations are linked to the ideal of self-determination through a state, whether as an aspiration, or, at the very least, as the memory of an administrative unity that approximated a state. This is clear from the very conflation of "nation" as nation-state (in the United Nations, for example), and "nation" as "people living in a state." ${ }^{\prime 4}$ In this sense nations are political communities. Secondly, it is widely agreed that nations are socially constructed. There have been a variety of paths to nationhood, depending on whether it has been imposed by elites, taken up as a national-popular movement, or linked to decolonization. ${ }^{5}$ But nations are not what nationalists take them to be: timeless communities "naturally" based on shared "race," culture, or language; 
they are modern phenomena that have been "imagined" out of selectively appropriated and invented traditions. Thirdly, since there are no objective criteria upon which to decide which social groups are "really" nations and which are not, it follows that the emergence of a particular nation depends ultimately on self-identification as such. As Gellner has it, "It is nationalism which engenders nations, and not the other way around. 6" An important peculiarity of the nation is, then, as Benhabib has argued, that it is socially constructed and yet experienced by those it for whom it forges a "special unity and belonging" as essential: as having clearly delineated and coherent boundaries which exist over time. ${ }^{7}$

Sociologists also agree that, in its essentialist mode, the nation is "an emotionally charged object." 8 For Anderson, the nation creates 'deep attachments' of fraternity that have made possible extraordinary sacrifices. ${ }^{9}$ For Gellner, nationalism involves righteous anger at the violation of the principle that nation and state should be congruent, or satisfaction at its fulfilment. ${ }^{10}$ Feelings of national belonging are also seen as central to the extension and consolidation of citizenship since they support a political community that requires sacrifice, seen primarily in gendered terms of military service and taxation. ${ }^{11}$ It is important to distinguish between different degrees of emotion that are felt for the nation, but also to note that they are differences of degree rather than of kind. As a feeling - rather than an ideology or a movement - nationalism is the same as patriotism, which is generally taken to involve love, but also pride in one's country, and usually a measure of hatred of the Other too. Once a nation-state is established, and in times of peace, feelings of national pride and solidarity may rarely be made explicit, though, as Billig has argued, it is in the "banal nationalism" of everyday life that ideological parameters are set, as the assumptions and symbols of "our" nation are 
"flagged."12 "National feeling" encompasses a range of emotions, from jingoistic patriotism to the tacit acceptance that nationality confers more than just a passport - an acceptance exhibited by the practically universal willingness to consider stereotypes of national character plausible. National feeling invariably involves a degree of loyalty, affection, and pride: feelings of belonging are also feelings of attachment to a nation that is, if not good in absolute terms, certainly better than its immediate neighbors, and that, whatever else the individuals and groups who make it up may have in common, has had and will continue to have a historic destiny.

As an ideal, cosmopolitanism is invariably opposed as "cool" to the "hot" emotions of nationalism. It is also opposed to national feeling as such: a cosmopolitan is "free from national limitations and attachments." 13 There have been recent attempts to think beyond this opposition, ${ }^{14}$ as well as studies of "actually existing cosmopolitanism," which are difficult to distinguish absolutely from transnational ethnonationalisms. ${ }^{15}$ In this paper we will focus on neo-Kantian understandings of cosmopolitan citizenship to be realized in legitimate human rights. ${ }^{16}$ In this usage, cosmopolitanism is close to that of the original Stoic idea of human beings as rational creatures with universal rights as citizens of the "cosmopolis." ${ }^{17}$ In terms of identity, it involves, above all, disidentification from the nation.

The emotional "coolness" of neo-Kantian cosmopolitanism is related to its basis in liberal-democratic human rights rather than in political community. This form of cosmopolitanism is secured by a commitment to autonomy that guides normative principles rather than by affective identification with one's fellows. Human rights are emotionally charged only by love of justice, altruism, or, as implied in Habermas's proposals for strengthening the legitimacy of human rights, by rationalized emotions of 
anger and resentment that have been worked on in deliberation to produce agreement on universals. ${ }^{18}$ It is hard to conceive of cosmopolitanism in terms of feelings of belonging to a political community because of the lack of global state, or even a world federation of states. Globalization does produce increased mutual interconnectedness and, arguably, a growing orientation towards global awareness. ${ }^{19}$ There are overlapping political constituencies of belonging that cut across national borders, of which transnational social movements and INGOs are the most significant organizations. These political movements are, however, very far from forming a global movement that might displace national feeling. In the absence of a global political community, then, how might cosmopolitanism compete with nationalist particularisms?

For neo-Kantians, the development of a cosmopolitan political community is necessary if human rights are to be legitimate. As Held argues regarding his proposals for cosmopolitan democratic law, human rights require the consent and support of voters in national political communities, not only for strategic reasons, but also in order to be genuinely democratic. ${ }^{20}$ For Habermas too, existing forms of politics provide only "weak legitimacy" for human rights, involving as they do the participation of elites rather than full debate in democratic societies. ${ }^{21}$ Processes of globalization have undoubtedly weakened the nation-state, but it is far from redundant. Since it is states that make, administer, and police human rights agreements, human rights claims may paradoxically reinforce the legitimacy of the national political community while at the same time altering traditionally indivisible state sovereignty. ${ }^{22}$ For human rights to be democratic, then, it is necessary that members of national political communities learn to think and feel beyond the limits of national interests, otherwise governments will continue to address voters on this basis and the gross inequalities of the New World 
(Dis)Order will remain, both within national borders and beyond. ${ }^{23}$

\section{The Social Construction of National Feeling}

To investigate the possibilities of creating a cosmopolitan political community, it is useful to study the emotions of "actually existing" cosmopolitanism. On the basis of such an investigation, I will suggest that, in some significant cases at least, national feeling is constructed within a moral order in which "real" emotions are figured as "human." This means that, under certain conditions, far from conflicting with national feeling, cosmopolitan emotions are actually implied in national feeling as such.

Since, as we have seen, it is generally agreed that the nation is socially constructed, an obvious place to begin enquiry into these issues is by considering the social construction of emotion. Indeed, the "social constructionist" aspect of both theories has much in common: like nations, emotions are not to be seen as "natural kinds," concrete, bounded "things" that exist in and of themselves; they are rather contingent, historically and contextually specific. The chief empirical difference between nations and emotions in this respect is that the nation is not embodied, even if it is sometimes symbolized in this way (in the tomb of the Unknown Soldier, for example). Harré argues that the temptation to abstract and reify emotion is particularly strong because of experiential embodiment: it is tempting to treat emotion as an "it" because of the way emotion is felt, often as a physiological agitation. However, this is to be resisted: once we begin to ask "what is an emotion?," our answers will only uncover the commonsense ways in which emotion has been constructed in the usage of particular languages. Emotions are nothing other than the meanings they are given by the use of "emotional vocabularies" in particular contexts. ${ }^{24}$ 
A theory of the social construction of national feeling risks being circular. Benhabib argues that in nationalism, and indeed in identity/ difference movements in general, essentialist vs. constructivist perspectives may be seen as corresponding to the standpoint of the participant in social and political life and the observer, respectively. ${ }^{25}$ In terms of emotion, however, understanding of the participant position seems to do no more than replicate the rhetoric of nationalism itself: nations exist, endure, and command self-sacrifice because they feel right to those who identify as nationals. For social constructionists, national feeling is nothing more than what is socially identified as such in particular contexts by those who experience and witness it.

There is a further consideration that complicates this simple account, however. In comparison with personal emotions like jealousy, anger, envy, or grief, love of one's country - while it must surely be considered as an emotion - is rather abstract. It may be thought of, following Barbalet's insightful sociological analysis of emotions, as a "macro-emotion," experienced collectively on a large-scale, beyond the face-to-face micro-social contexts that are the main focus of psychological studies of the social construction of emotion. ${ }^{26}$ This gives rise to particular theoretical and methodological difficulties. National feeling fulfills all the criteria social constructionists of emotion have identified for the use of emotion words: it may well involve bodily agitation; it is intentional - it is "about" the nation; and it certainly involves a local moral order of rights, obligations, duties, and conventions of evaluation. ${ }^{27}$ However, its abstract status as a "macro-emotion" complicates national feeling and makes it peculiarly suspect in any particular case. As Barbalet puts it in his discussion of class resentment: "One problem ... with any account which focuses upon groups rather than individuals, is that the actual emotional experience of any given person at any time will not correspond 
with the analogous 'micro-emotion."'28 Using an analysis of media coverage of the "war against terrorism" following the attack in New York on September 11, I want to suggest that national feeling is indeed complex, both "micro" and "macro," involving personal emotions that are encompassed as aspects of national feeling. Moreover, national feeling is understood in precisely this way by many of those who experience it: as consisting of empathetic identifications with others who feel certain emotions because they are human. It is because personal emotions and "humanist" sympathy are reflexively intertwined in national feeling in this way that "actually existing" cosmopolitanism is, under certain conditions, experienced as an extension of legitimate national feeling rather than as opposed to it.

The analysis will be focussed on the website set up to canvass "Readers' Opinions" on the "Portraits of Grief" series that ran in The New York Times until December 31, 2001. It is important to note that the example is not intended to prove that national feeling and "humanist" sympathy are intertwined emotionally, but nor is it being used simply to illustrate the theory. The point of using this example is rather to contribute to thinking through the relationship between national feeling and "humanist" sympathy in a concrete case. The example allows us to explore how at moments of heightened emotion national feelings of belonging are experienced temporally in a way that makes them impossible to separate absolutely from strong feelings about people who are "like us," not just as fellow nationals but also as human beings. It is not difficult to find counterexamples in which the non-national Other continues to be interpreted as less-than-human. I am suggesting, however, that the logic of national feeling is such that under certain conditions, even where it is at the "hot" end of the scale, as it was in the US after 9/ 11, it may be "convertible" into what I will call "popular cosmopolitanism." 
The "war" on terrorism is, of course, unlike typical wars in many ways. It did, however, intensify national feeling in the US and this intensity is prominent in "Portraits of Grief."29 The "Portraits of Grief" themselves are short, simply written obituaries of those who died in the Twin Towers. They emphasize the "ordinariness" of those who died and are far from explicitly patriotic. The fact of American nationality is not even noted - it is assumed - and other countries appear to be mentioned only as incidental facts of some people's lives: one man retained his Indian citizenship, for example; another married a woman from his hometown in Italy. In this respect, the "Portraits of Grief" are celebrations of individuality rather than of nationality. Nevertheless, The New York Times is a national newspaper and, as we would expect, many of the readers who wrote to the web forum express themselves as belonging to the "imagined community" of America through these reports.

Many of the emails, unsurprisingly, explicitly enact a sense of national belonging "To the families of the victims: the whole country shares your grief" (from "thechunk" Dec 5); "to pay homage to all the beautiful lives we lost" (italics added; from "tkeene" Dec 5); "with love to my fellow Americans and to those in the world that are standing with us" ("melmunch" Dec 7); and so on. Furthermore, many of those that do not thematize American belonging explicitly nevertheless end their messages with "God Bless America" (though, as a marker of belonging, this is complicated by the fact that one of these identifies herself as Chinese and living in China ("jo-jo lam" Dec 31)). There are also a number that enact a more cosmopolitan sense of solidarity, explicitly criticizing American patriotism and calling for wider identifications: "let us be aware that we alone do not suffer this trauma, but it happens all over the world" (from "Andrew" Dec 11); "I suggest that we spend a lot more time asking each other what it is 
we value about being Americans. If it's living without regard for the rest of the world, we are fools" (from “derrelldurrett” Dec 20); “We need to see 'Portraits of Grief' for the victims of the bombings in Afghanistan and Iraq" (from "dclearwaters" Dec 23).

The expressions of national solidarity here are self-evidently "hotter" than those of cosmopolitanism, which appear to be more critical and reflective than emotive. Importantly, however, these "hot" expressions of national feeling gain much of their emotional charge from the context in which they are embedded: they are almost invariably intertwined with personal feelings of shock, grief, or sympathy. In a way this is simply produced by the question "How has your own life changed since the attacks?" that solicited responses to the "Portraits of Grief." The writers almost always make reference to the suffering of individuals and families who died, or who were close to or knew someone who died, as a result of the attack on the World Trade Centre. The implication, sometimes made explicit, is that we know, understand, and share what they are feeling because we too have suffered injury or bereavement in our personal lives. In this way, national feeling is constructed out of empathetic identification with the personal feelings of fellow nationals.

However, many of the emails also implicitly point beyond the limits of nationality in their appeals to empathize with personal suffering: they rely on an understanding of what others must feel because they are human. Often the writer invokes the commonality of "human" suffering by describing how they themselves feel: "J ust imagining how many grieving families and friends are out there seemed overwhelming" (from "stefr" Dec 5); "I find every day to be a struggle, to see faces on the train that also see life as a struggle" (from "dtsalvati" Dec 6). Sometimes the writers link "human" suffering to more personal feelings of loss and pain, making reference to loss in their 
own life, whether directly related to the events of September 11 or not. More usually, however, they simply assume that "we," the readers, understand and share these feelings, or they demand what "should be" a shared response: "if we imagine the pain of the victims families, this should make us realize how precious life is and not to worry about little things" (from "shahla7" Dec 5th); “I am Californian and felt my heart was broken the day of Sept 11, 2001. Everybody at work was feeling the pain every person that has a heart felt" ("123456162" Dec 31). Alternatively the grief is felt to be unimaginable, and therefore knowable as such: "I cannot imagine the sorry and grief they friends and families feel, but nevertheless, my thoughts and heart will be forever with them" ("sansan16" Dec 20).

In this way, then, feelings of national belonging are constructed through personal emotions that are understood to be common to all humans. National feeling is constructed in "Portraits of Grief" as a "macro-emotion" in that it is assumed that fellow nationals all feel the same way about the same events: "we" feel together as a nation who is reading and writing to a forum organized in the name of a national newspaper. However, the feelings themselves are not oriented to the nation, nor, in the great majority of cases, are they expressed for others specifically as Americans. They are shared and understood as feelings "anyone would/ should have" if they were to put themselves in the position of individuals and families who feel the "human" emotions of love, grief and loss. In this respect, the "micro-feelings" that bring us together as a nation are not limited to fellow nationals: they are universal, personal emotions. "Humanist" sympathy is occasionally made explicit in these emails: "It is a blessing to be reminded of the sanctity of every human life, even as we are happy to learn and celebrate all the ways the lost beloved fold lived life to its fullness" ("hill634" Dec 13); 
"People were mourning and sad, but at the same time the tragedy brought the best out of everyone - people going out of their way to help others, people consoling perfect strangers - in a city that is renowned to be all rush, rush, rush..." ("sansan16" Dec 20). "Humanist" sympathy is nevertheless implicit, where it is not explicit, in all the appeals to a common sense of emotional experience.

Implicit "humanist" sympathy is clear if we consider how inappropriate an expression of emotion that articulated nothing but a love of country and sympathy for others only because they are fellow nationals would be in such a context. The moral order within which national feeling makes sense is evident in these emails insofar as, although it is not an interactive forum, "excesses" of emotion do receive correction. There are actually only two types of emails that produce a response from readers of "Portraits of Grief" who write in to The New York Times website. The first is in response to expressions of grief that seem excessive in proportion to the writer's direct personal experience of bereavement. The second is in response to those, relatively rare, interventions that vow revenge on "our" enemies in the name of those fellow nationals who are suffering. The two are often linked in that excess in the first case is rebuked as giving fuel to excess of the second kind, as in the following message:

OK, I'm going to offer what may be a 'politically incorrect' statement, but bear with me... Unless you had someone that you know directly die in the attack(s), I don't believe that you should still be in grief. Personally, my life hasn't really changed that much...I worry more about the future now, I guess, since the anti-terrorism hyperbole that has erupted after 9/11 has helped push two countries to the brink of nuclear war, and I'm afraid that, in the future, it will be easy to simply point a finger at someone and yell 'terrorist,' as easy as it was to point a finger and yell 'witch' in the past. ("tamcmahan66" J an $2^{\text {nd }}$ 2002) 
This was followed next day by a supporting message: "it is time to stop reveling in our schizophrenic patriotism and grief, which has done nothing more than stoke the fire of national hate" ("nadimk" J an 3). It would seem that, in this context at least, it is more legitimate to suffer personal emotion as an individual or a member of a family who has been bereaved, or to offer sympathy to those fellow nationals who have suffered, than it to express abstract "national grief" or "militaristic nationalism." There is a moral order at work here within which national feeling is being constructed: "proper" national feeling is limited to sympathies for others based on "what they must feel as we would feel if it were our personal grief." It is not that nationalism necessarily gives way to cosmopolitanism in such a moral order. It is rather that "humanist" sympathy enables the contestation of what is reasonable and right as a response to the nation's enemies. In these responses to the events of September 11, nationalism is contested primarily in terms of emotions: both strategic and normative reasoning is secondary. What is right as a response to the nation's enemies must be grounded in proper emotions, which are personal and human rather than simply patriotic.

This analysis shows how "humanist" sympathies, personal emotions, and nationalist sentiments are interrelated in twenty-first century America, even - or perhaps especially - at times when national feeling is heightened. The specificities of the analysis may be limited to the setting of liberal America. The New York Times is a liberal newspaper in which we would expect to find nationalism tempered by "humanism", in comparison with other US media. The question "How has your own life changed since the attacks?" may be seen as peculiarly productive of emotional response from those schooled in "intimate citizenship."30 Finally, insofar as "humanist" sympathy is historically and culturally specific, it may be that nationalism outside the West is not 
experienced in the same way. Nevertheless, there are reasons to suppose that the analysis made of this particular case may have more general significance. Firstly, the geopolitical importance of the US makes it particularly significant for the extension and securing of cosmopolitan human rights. We will examine this issue more closely in the final section of the paper. And secondly, there seems no reason to suppose that national feeling is less complex in other settings if we consider that emotion is necessarily experienced as embodied and temporal.

Barbalet's temporal theory of emotions gives us a way to think the complexity of the social construction of national feeling. If, he argues, social life is understood as process, in which actors, structures, and institutions are always becoming rather than in a state of fixed, essential being, then emotion too should be understood as social process (rather than as a product of social management). Moreover, emotion should not be understood in exclusively cognitivist terms, a tendency Barbalet criticizes in social constructionism. Following Spinoza, he argues that "emotion can be neither hindered nor removed except by another emotion." 31 In the case of national feeling, then, it is necessarily provoked in relation to, and temporally limited by, other, equally strong emotions. As we have seen, personal feelings, feelings for others, and feelings for the nation succeed and strengthen each other in the process in which attachments to the nation are constituted. National feeling is also limited in relation to personal emotions and "human" sympathies in the moral order through which nationalism is constructed. This moral order - at least in twenty-first century America, influenced historically by "sentimental citizenship" requires that national feeling should exist in relation to other, deeply-felt but limited personal emotions and "human" sympathies. To return to Benhabib's puzzle over how it is that the nation is constructed and yet experienced as 
essential, nationalism does involve the feeling that "I belong to a nation that is unified, coherent, and enduring," but those feelings of belonging are not themselves unified, coherent, and enduring.

\section{Cosmopolitan Citizenship}

In the absence of a world state, the extension of human rights gives some substance to the idea of cosmopolitan citizenship. Human rights are being extended by "noncoercive" means through the institutions of the UN and the EU. They are also, more dramatically, being extended through new forms of war, both in "humanitarian interventions" and in peace settlements. ${ }^{32}$

Western governments, ultimately answerable to the electorate, must justify getting involved in wars of humanitarian intervention that may lead to loss of citizens' lives and that cannot be described very convincingly as serving national interests. Humanitarian wars require compassion and support for altruistic action on the part of governments and voters who are also taxpayers. The ongoing "war against terrorism" is undoubtedly ambiguous in this respect: declared on the grounds of US national security, the bombing of Afghanistan was, however, carried out by the military coalition in the name of humanitarian intervention, to overthrow the Taliban and restore Afghanistan to its people. Martin Shaw has argued that the impetus for humanitarian interventions has generally come less from national states than from the media, which solicit compassion using the themes of "humanist" sympathy that, as we have seen, are also productive of nationalist feeling. 33 We are by now all familiar with the portrayal of war leaders who bring ruin to the country and distress and suffering to "innocent people." The separation of "the people" from warmongers enables an identification across national differences 
that is solicited on the basis of human feelings: though they differ from us in various ways, nevertheless "ordinary people" suffer the same "micro-emotions" we would feel in their situation, losing friends, family, homes, jobs, and education as a result of religious persecution and war. In the case of the war in Afghanistan, the emphasis of human interest stories was on refugees and on women's lives under the Taliban.

It is in the soliciting of human identification across national differences that we see "popular cosmopolitanism" as an extension of the complexity of emotions that make up national feeling rather than in dichotomous opposition to it. In some cases, "popular cosmopolitanism" certainly is in tension with national feeling. As one contributor to the "Portraits of Grief" (who had lost his sister and who was not "corrected" for excessive emotion) wrote: “I am filled with hatred for people I do not know nor understand. I have no pity for the starving children or their parents. I only feel they deserve it for all the death their people have caused here" ("jsaladino1" J an 11). On other occasions, however, it is possible to go so far as to figure "popular cosmopolitanism" as a hybrid form of “cosmopolitan patriotism.” In response to President Bush's suggestion that every American child give \$1 to help Afghan children survive the winter, one child wrote: "there is a lot that we can do to help people, not only Americans but the children that are starving and hurting inside.... Doing this wonderful act of kindness just shows what a wonderful country we are" ("Gina" http:// www.nytimes.com/ learning/ students/letters/).

"Popular cosmopolitanism" is, of course, highly volatile and erratic: it seems only rarely to extend to asylum-seekers, for example, especially where conflicts over local resources are in question, and it rarely implicates individuals in acts of generosity or independent action against injustice. ${ }^{34}$ The uneven and contradictory development of 
"popular cosmopolitanism" is no doubt linked in part to its emergence as "consent to global rule" by Western powers extending human rights by military force. Is it possible that in this respect "popular cosmopolitanism" is following an historical trajectory much more like that of nationalism than would be expected, given an understanding of "hot" nationalism as opposed to "cool" cosmopolitanism? It may be that, in extending human rights by force, western states acting in coalition are a "state conglomerate," a multinational bloc that forms an effective center of power through which successful wars can be prosecuted. ${ }^{35}$ In this sense, "popular cosmopolitanism" may be closely tied to the development of the "Western state," just as nationalism is tied to the development of the nation-state.

I have argued that the distinction between "hot" nationalism and "cool" cosmopolitanism reifies the former and idealises the latter. In relation to the western state, cosmopolitanism is less likely to be based on "cool" altruism than on sympathy with human suffering, understanding of personal emotions, and even, paradoxically, heightened feelings of national feeling in "new wars." Although fear and hatred of enemies both outside and inside the nation should not, of course, be underestimated, what makes humanitarian intervention "right" for the citizens of the West is less likely to be the reasoned principles with which cosmopolitanism is associated in neoKantianism, than sentimental "popular cosmopolitanism" that makes it feel right. As Arendt argued, compassion justifies violence against those who cause suffering, obviating the need for "wearisome processes of persuasion, negotiation, and compromise."36 The media is much better at representing people in conflicts as victims than as protagonists; newspapers and TV reports rarely take seriously the selfrepresentations of those in conflict situations, and they tend to take their cue from 
Western governments and international organizations. ${ }^{37}$ The extension of human rights by military means that is justified by "popular cosmopolitanism" does not require a highly engaged, democratic process of negotiation.

Clearly, "popular cosmopolitanism" is very far from the neo-Kantian ideal. It may therefore be argued that it is not cosmopolitanism at all. However, neo-Kantians tend to be ambivalent about the extension of human rights by force. 38 The most difficult question for those committed to cosmopolitan democracy is surely whether the democratic institution of human rights is made more or less unlikely by their extension into undemocratic countries, however that is achieved. A further pragmatic question concerns the emotional resources on which substantive human rights might draw. If citizenship rights within state borders have relied on national feeling to underpin political community, might not substantive human rights that require redistribution of wealth, ecological awareness, and self-sacrifice have to rely on the rather dubious emotional identifications of "popular cosmopolitanism," rather than on the rational deliberations of an informed and impartial democratic public?

\section{NOTES}

\footnotetext{
${ }^{1}$ Kant, Political Writings (Cambridge: Cambridge University Press, 1991), 45.

${ }^{2}$ Bryan Turner, "Liberal Citizenship and Cosmopolitan Virtue," in A. Vandenberg, ed., Citizenship and Democracy in a Global Era (Basingstoke, Hants: Macmillan, 2000).

${ }^{3}$ The distinction between "hot" and "cool" is similar to Hume's analysis of "calm" and "violent" emotions. According to Hume, "calm" emotions are often confused with reason, though "[r]eason is, and ought only to be the slave of the passions" and "violent" emotions that are relatively constant are most likely to motivate us to action. David Hume, A Treatise of Human Nature (Oxford: Clarendon, 1978), 415.

${ }^{4}$ See Michael Billig, Banal Nationalism (London: Sage, 1995), 24.

${ }^{5}$ E.J. Hobsbawm, Nations and Nationalism since 1780: Programme, Myth, Reality (Cambridge: Cambridge University Press, 1990).

${ }^{6}$ Ernest Gellner, Nations and Nationalism (Oxford: Blackwell, 1983). The chief opponent of the view that nations are modern social constructions is Anthony Smith. We will not deal with this debate here, except to note that one of his objections to the argument is that social constructionists under-estimate "hot" loyalty to the nation. Anthony Smith, Nations and Nationalism in a Global Era (Oxford: Polity, 1995), 39-40.
} 
${ }^{7}$ Seyla Benhabib, "Democracy and identity: in search of the civic polity" in Philosophy and Social Criticism 24, no. 3 (1998): 85-100.

${ }^{8}$ Monserrat Guibernau and John Rex, "Introduction,” Guibernau and Rex, eds., The Ethnicity Reader: Nationalism, Multiculturalism and Migration (Oxford: Polity, 1997), 4.

${ }^{9}$ Benedict Anderson, Imagined Communities: Reflections on the Origins and Spread of Nationalism (London: Verso, 1991): 7.

${ }^{10}$ Gellner, Nations and Nationalism, 1.

${ }^{11}$ Jurgen Habermas, The Postnational Constellation: Political Essays (Oxford: Polity, 2001), 64-5. The direct

"emotion work" that women as citizens are required to do generally goes unacknowledged in mainstream writing on citizenship. See Carole Pateman, The Disorder of Women (Oxford: Polity, 1989).

${ }^{12}$ Billig, Banal Nationalism.

${ }^{13}$ Oxford English Dictionary, quoted in David Held, Democracy and the Global Order: From the Modern State to Cosmopolitan Governance (Oxford: Polity, 1995), 227.

${ }^{14}$ Gerald Delanty, Citizenship in a global age: Society, culture, politics (Buckingham: Open University Press, 2000). See also the discussions in J. Cohen, ed., For Love of Country: Debating the Limits of Patriotism (Boston: Beacon, 1996) and in B. Turner, "Cosmopolitan Virtue: Globalization and Patriotism," Theory, Culture and Society 19, no. 1-2 (2002): 45-63.

${ }^{15}$ Bruce Robbins, “Actually Existing Cosmopolitanism,” in P. Cheah and B. Robbins, eds., Cosmopolitics: Thinking and feeling beyond the nation (Minneapolis: University of Minnesota Press, 1998).

${ }^{16}$ Jurgen Habermas, "Bestiality and Humanity: a War on the Border between Legality and Morality," Constellations 6, no. 3 (1999): 263-72; Habermas, The Postnational Constellation; Held, Democracy and the Global Order.

${ }^{17}$ Held, Democracy and the Global Order, 227.

${ }^{18}$ Habermas, The Postnational Constellation, 110-11.

${ }^{19}$ Martin Albrow, The Global Age (Cambridge: Polity, 1996).

${ }^{20}$ Held, Democracy and the Global Order.

${ }^{21}$ Habermas, The Postnational Constellation, 108-9.

${ }^{22}$ Yasemine Soysal, "Postnational Citizenship: Reconfiguring the Familiar Terrain,” in K. Nash and A. Scott, eds., The Blackwell Companion to Political Sociology (Oxford: Blackwell 2001).

${ }^{23}$ Habermas, The Postnational Constellation, 112.

${ }^{24}$ Rom Harré, The Social Construction of Emotions (Oxford: Blackwell, 1986).

${ }^{25}$ Benhabib, "Democracy and identity: in search of the civic polity," 93

${ }^{26}$ J.M. Barbalet, Emotion, Social Theory and Social Structure: a Macrosociological Approach (Cambridge: Cambridge University Press, 2001), 71.

${ }^{27}$ Harré, The Social Construction of Emotions, 8.

${ }^{28}$ Barbalet, Emotion, Social Theory and Social Structure, 71.

${ }^{29}$ http:www.nytimes.com/pages/national/portraits/ (downloaded 15.1.02).

${ }^{30}$ See Lauren Berlant, The Queen of America Goes to Washington City (Durham: Duke University Press, 1997).

${ }^{31}$ Barbalet, Emotion, Social Theory and Social Structure, 181; Benedict De Spinoza, Ethics (Harmondsworth, Middlesex: Penguin, 1996). Barbalet is also close to Hume on this point. See Hume, A Treatise of Human Nature.

${ }^{32}$ Mary Kaldor, Old and New Wars: Organized War in a Global Age (Cambridge: Polity, 1999). The principle is not itself new. Kant considered intervention into states torn apart by civil strife legitimate, though he otherwise upheld the principle of state sovereignty. In fact, it may be seen as a principle that is integral to state-building and the construction of the interstate system itself. See Bertrand Badie, The Imported State: The Westernization of the Political Order (Stanford: Stanford University Press, 2000).

${ }^{33}$ Martin Shaw, Civil Society and Media in Global Crises: Representing Distant Violence (London: Pinter, 1996).

${ }^{34}$ Stan Cohen, States of Denial: Knowing about atrocities and suffering (Oxford: Polity, 2001).

${ }^{35}$ Martin Shaw, "The Kosovan War, 1998-99: Transformations of State, War and Genocide in the Global Revolution,” Sociological Research Online (4/2, http://www.socresonline.org.uk/4/2/shaw.html 1999).

${ }^{36}$ Hannah Arendt, On Revolution (Harmondsworth, Middlesex: Penguin, 1990), 87.

${ }^{37}$ Shaw, Civil Society and Media in Global Crises, 182.

${ }^{38}$ Habermas, "Bestiality and Humanity”; David Held, 'Violence, Law and Justice in a Global Age,' http://www.ssrc.org/sept11/essays/held.htm (downloaded 21.1.2002). 